\title{
A NEW RECORD AND BIOLOGICAL EVIDENCE SUPPORTING THE ESTABLISHMENT OF BERYX SPLENDENS (ACTINOPTERYGII: BERYCIFORMES: BERYCIDAE) IN THE WESTERN MEDITERRANEAN BASIN
}

\author{
Davide DI BLASI ${ }^{1 *}$, Erica CARLIG ${ }^{1}$, Sara FERRANDO ${ }^{2}$, Laura GHIGLIOTTI ${ }^{1}$, \\ Peter N. PSOMADAKIS ${ }^{3}$, and Marino VACCHI ${ }^{1}$ \\ ${ }^{1}$ Institute of Marine Sciences (ISMAR), National Research Council (CNR), Genoa, Italy \\ ${ }^{2}$ Department of Earth, Environmental and Life Sciences (DISTAV), University of Genoa, Genoa, Italy \\ ${ }^{3}$ Food and Agriculture Organization of the United Nations (FAO), Rome, Italy
}

Di Blasi D., Carlig E., Ferrando S., Ghigliotti L., Psomadakis P.N., Vacchi M. 2018. A new record and biological evidence supporting the establishment of Beryx splendens (Actinopterygii: Beryciformes: Berycidae) in the western Mediterranean basin. Acta Ichthyol. Piscat. 48 (2): 183-188.

\begin{abstract}
A new specimen of splendid alfonsino, Beryx splendens Lowe, 1834, was caught by trawling in July 2016 in the Ligurian Sea at the depth of $350 \mathrm{~m}$, in the proximity of a submarine canyon. It represents the 10th documented record of $B$. splendens in the Mediterranean. Because of the rarity of the records in the basin, there could be doubts whether to consider or not such species as established in the area. However, some findings may support the hypothesis of the possible establishment of the species in the Mediterranean Sea. For example, the stomach of the specimen was nearly full, with rests of one crustacean decapod, one fish, and some cephalopods, which are commonly reported prey items for the species. Macroscopic observation and histological analysis of the gonads revealed that the specimen was a male in an advanced stage of gonadal development. Finally, the coherence of habitat type and prey items with that of extra-Mediterranean populations coupled with gonadal maturation consistent with the observations on other specimens caught in the Mediterranean.
\end{abstract}

Keywords: splendid alfonsino, Beryx splendens, exotic species, Mediterranean Sea, Ligurian Sea, new record, stomach contents, gonad analysis

\section{INTRODUCTION}

The genus Beryx is composed of three species. Two of them, the splendid alfonsino, Beryx splendens Lowe, 1834, and alfonsino, Beryx decadactylus Cuvier, 1829, are worldwide distributed in the oceans, where they live in the proximity of the rocky bottom of continental slopes and seamounts, down to the depth of 1300 meters, preferably in warm and temperate waters (Busakhin 1982, Orsi Relini et al. 1995). The third, more recently described species, Beryx mollis Abe 1959, seems to be confined to the China Sea and western Indian Ocean (Akimoto et al. 2006).

In the Mediterranean Sea, only the two former species have been sporadically reported. Four Beryx decadactylus specimens were recorded between the late 19th and early 20th centuries off Nice in 1885 (Bellotti 1891, Orsi Relini et al. 1995), off Camogli (Genoa) in 1899 (Ariola 1904, Orsi Relini et al. 1995), off Vada (Livorno) in 1907, and off Catania in 1908 (Orsi Relini et al. 1995). The first occurrence of Beryx splendens in the Mediterranean waters was reported by Gavagnin et al. (1992) through the analysis of a good quality photo taken on a specimen caught by bottom drop lines off Nice. A second specimen was subsequently trawled off Genoa in 1993 (Orsi Relini et al. 1995). The third catch of B. splendens in Mediterranean Sea (the first from outside the Ligurian Sea) was carried out in 2001 by a trawler targeting deep-water shrimps off the coast of Anzio (central Tyrrhenian Sea) (Psomadakis et al. 2006). Subsequent specimens were all captured in the Tyrrhenian Sea: by bottom drop-lines in 2007 off the Cilento coast (Psomadakis et al. 2012b), by bottom trawls in 2009 off the Monte Argentario Promontory (Ligas et al. 2010), and off Cape Carbonara (Follesa et al. 2011), and again off the Cilento coast in 2010 by bottom trawl (Psomadakis et al. 2012b). In addition, two unpublished records were reported by Orsi Relini (2010); these latter specimens were caught off Portofino (Ligurian Sea) and off the Calabrian coast (southern Tyrrhenian Sea). In all cases, the fish were caught by deep-sea fishing gears (longlines and trawl nets) at depths between ca. 100 and $1000 \mathrm{~m}$.

Given the absence of Beryx splendens in the Red Sea and its presence in the Atlantic waters, ingression of 
pelagic larvae (Lehodey et al. 1997) or adults from the Strait of Gibraltar is supposed to be the way of entrance of B. splendens into the Mediterranean Sea (Orsi Relini et al. 1995, Follesa et al. 2011).

The rarity and the scattered distribution of the Mediterranean records resulted in the inclusion of Beryx splendens in the CIESM Atlas of exotic species in the Mediterranean Sea, with the status of alien species of Atlantic origin (Golani et al. 2002, 2013, Psomadakis et al. 2012a). Alternatively, some authors consider $B$. splendens a species of Atlantic origin recorded in the Mediterranean as a consequence of a natural range expansion and not as "aliens", because their migrations were not human mediated (Zenetos et al. 2012, Iglésias and Frotté 2015).

In this paper, we report a new record of Beryx splendens, and discuss the possible establishment of the species in the western Mediterranean Sea.

\section{MATERIALS AND METHODS}

The specimen of Beryx splendens (Fig. 1) was caught by the commercial fishing trawler D'Ercole Padre in the early July 2016 in the Gulf of Genoa $\left(44.31033^{\circ} \mathrm{N}, 008.76917^{\circ} \mathrm{E}\right.$; Ligurian Sea, north-western Mediterranean Sea) at about $350 \mathrm{~m}$ depth, near the edge of the slope, in the vicinity of a submarine canyon. Upon collection, the fish was frozen and stored at $-20^{\circ} \mathrm{C}$ for further analysis.

In the laboratory, morphometric and meristic data were acquired to assure a correct identification of the species, based on the features described by Maul (1986), Yoshino et al. (1999), Yoshino and Kotlyar (2001), Moore (2002), and Kotlâr (unpublished*) (Table 1). Measurements were made with an accuracy of $0.1 \mathrm{~cm}$ using a measuring board with a sliding cursor. Measurements and counts were taken following Holden and Raitt (1974). The degree of stomach fullness was assessed following Lebedev (1946). Stomach contents were identified and the digestion degree of the contents was determined following Magnuson (1969). Sex and maturity stage was determined according to Holden and Raitt (1974). A little portion of gonad was taken and fixed in a $4 \%$ paraformaldehyde solution, embedded in paraffin wax, and $5 \mu \mathrm{m}$ sections were stained with haematoxylin-eosin for subsequent histological analysis based on the maturity scale proposed by Lehodey et al. (1997).

After analysis, the specimen was preserved frozen and deposited in the collection of the National History Museum of Genoa with the voucher number MSNG 60133.

\section{RESULTS}

The specimen (Fig.1) measured $35.2 \mathrm{~cm}$ in standard length (SL), and $37.4 \mathrm{~cm}$ in fork length (FL). Total weight of the whole and the gutted specimen was $1078.7 \mathrm{~g}$ and 997.4 $\mathrm{g}$, respectively. The stomach was nearly full corresponding to stage IV of the Lebedev's scale (Lebedev 1946). The high state of digestion of the content, stage IV according to Magnuson (1969) prevented us from identifying prey items to lower taxonomic levels. However, we could recognize the remains of one decapod crustacean, one fish, and some cephalopods. Stomach contents were kept and preserved in $70 \%$ ethanol. According to macroscopic observations of the gonads, the specimen was a male at the stage of maturation IV (near spawning) (Holden and Raitt 1974). Histological observations revealed a slightly earlier stage of maturation, with the presence of spermatocytes I and II, spermatids, and spermatozoa (Fig. 2), corresponding to stage $4-5$ of the maturity scale described by Lehodey et al. (1997).

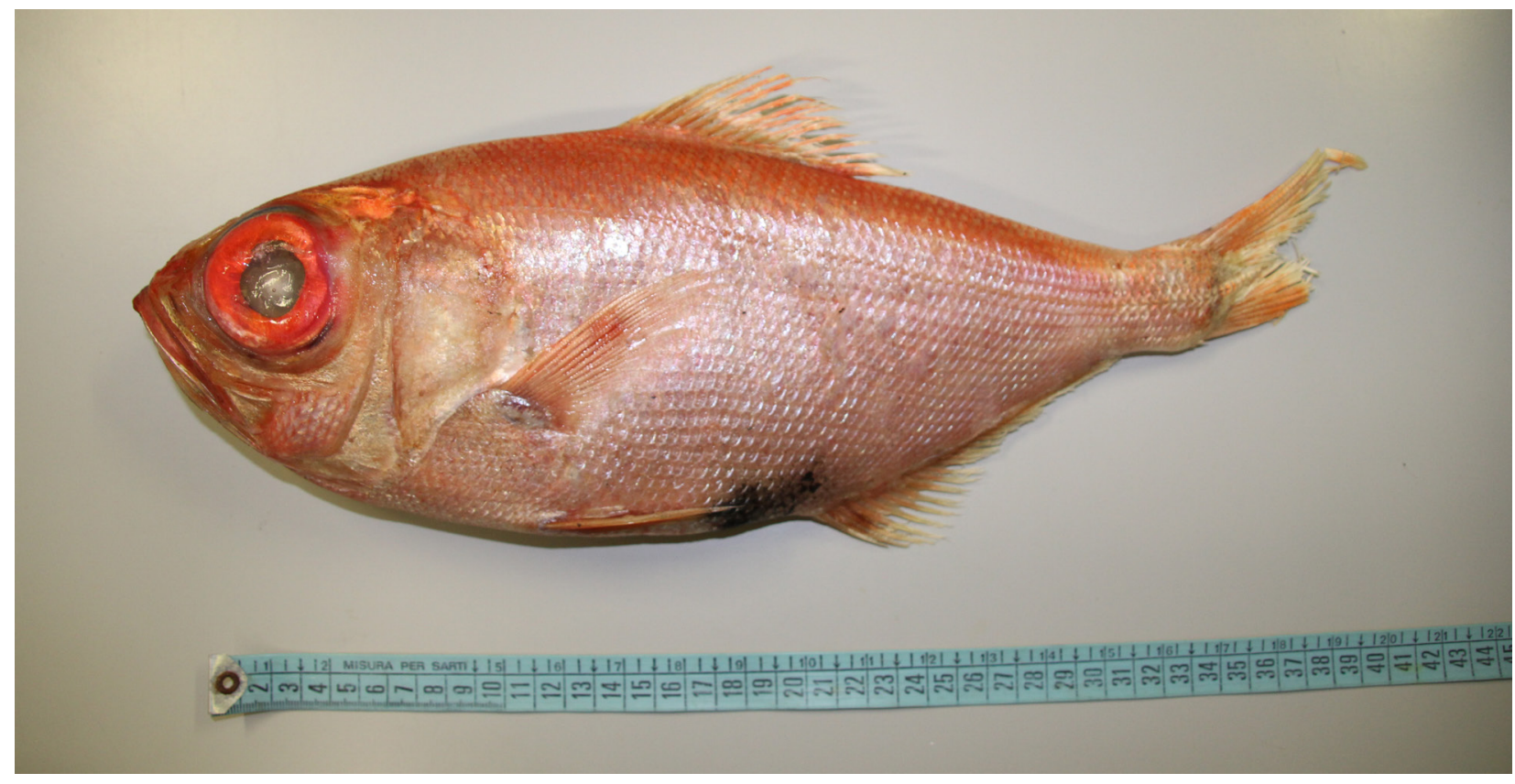

Fig. 1. Beryx splendens (352 mm SL) caught in the Gulf of Genoa, Italy, in July 2016 at a depth of about $350 \mathrm{~m}$ and deposited in the collection of the National History Museum of Genoa: voucher number MSNG 60133 


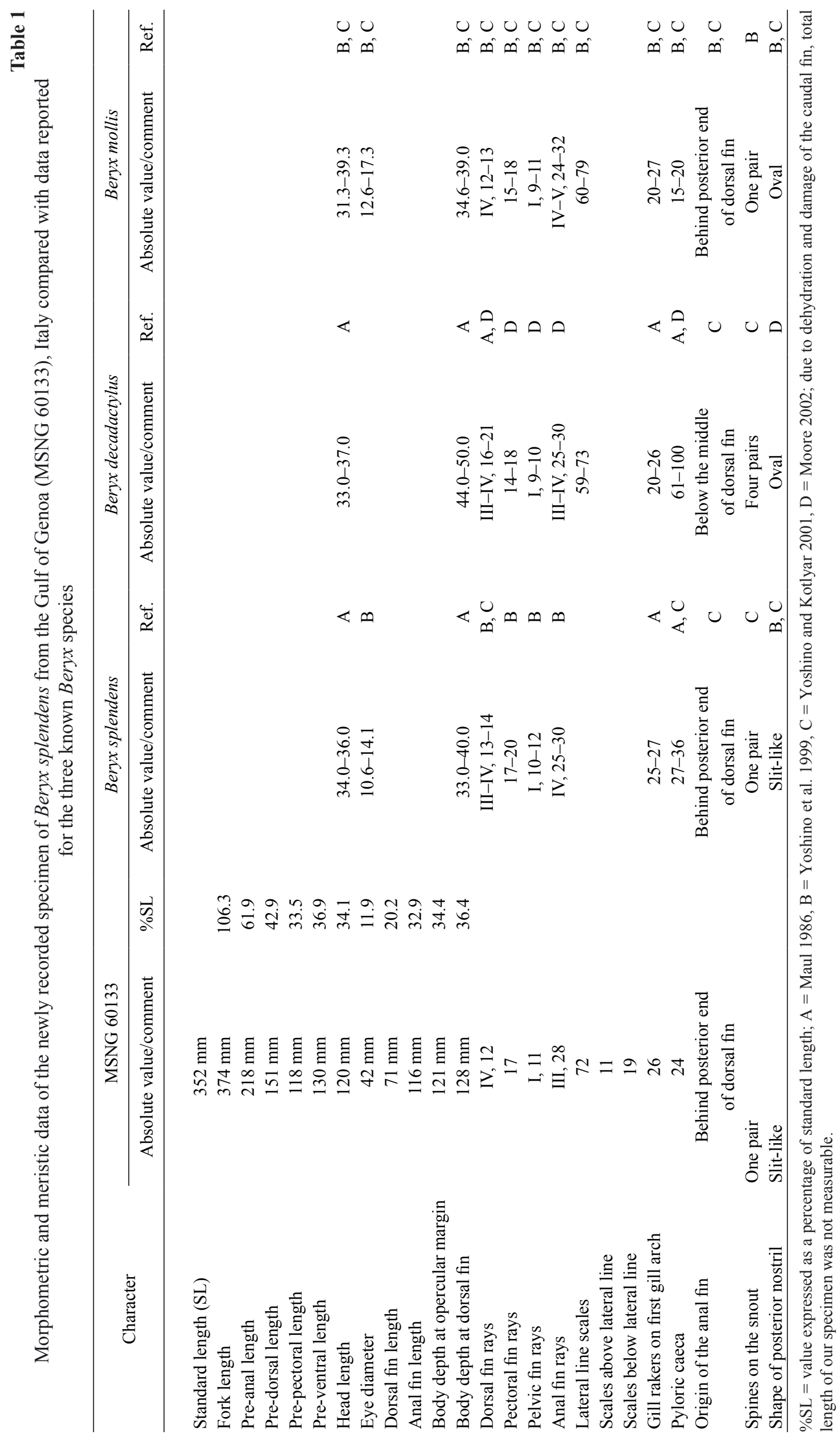




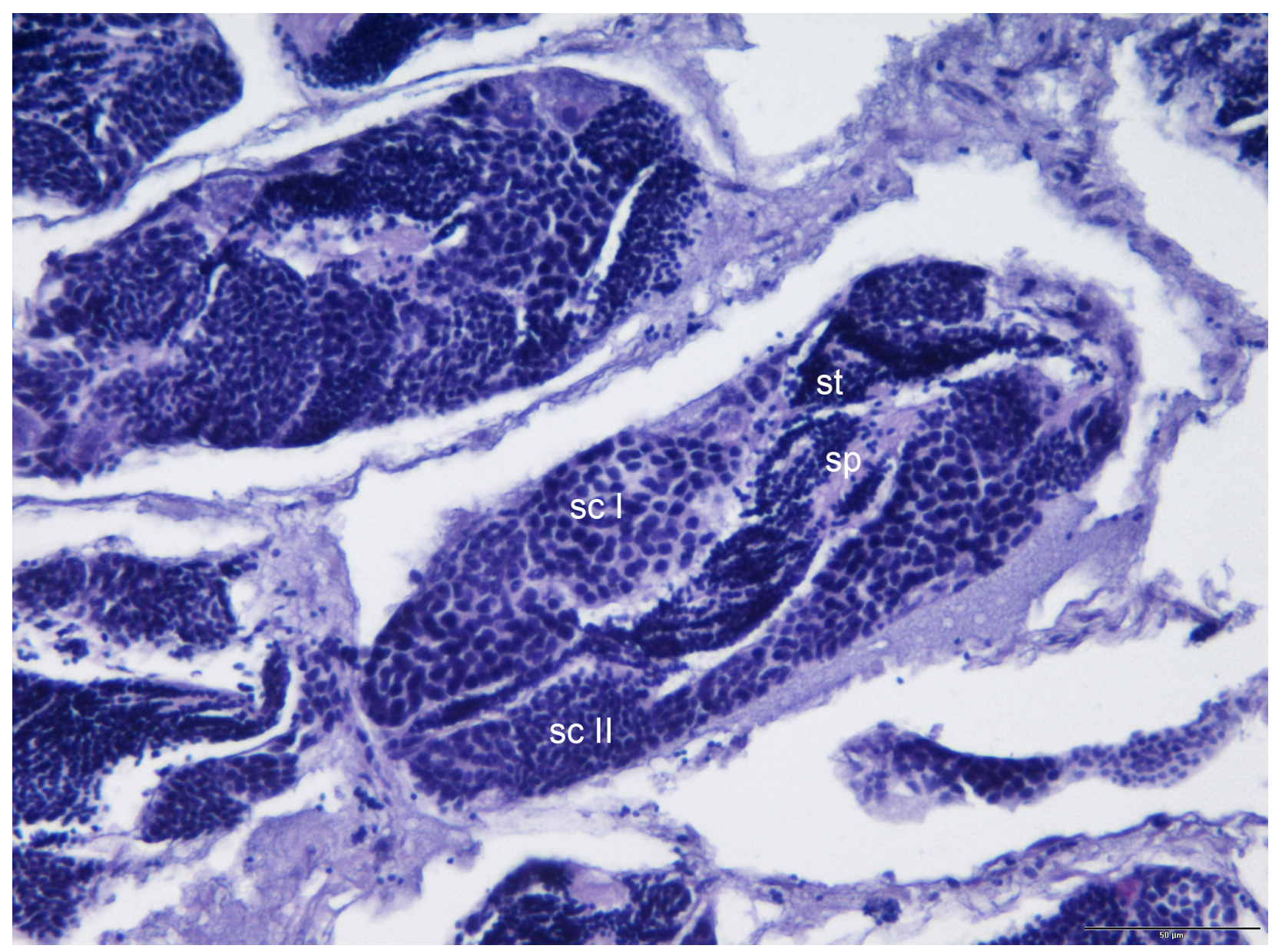

Fig. 2. Histological section of the male gonad of Beryx splendens from the Gulf of Genoa, Italy: haematoxylin-eosin; sc $\mathrm{I}=$ spermatocytes I, sc II = spermatocytes II, st = spermatids, $\mathrm{sp}=$ spermatozoa; scale bar $=50 \mu \mathrm{m}$

\section{DISCUSSION}

The habitat and the depth at which the new specimen was caught were typical for this species. As suggested by Ligas et al. (2010) and Psomadakis et al. (2012b), the paucity of records in the Mediterranean waters could be due not only to the rarity of the species but also to the sampling difficulties in such areas. Hard submarine structures are difficult to access for sampling activities (Danovaro et al. 2010) and deep long-lines and bottom drop-lines, the main gears used for fishing this species (Horn and Massey 1989, Rico et al. 2001), are less common in the Mediterranean than in the Atlantic (Rico et al. 2001). As a consequence, the areas in which Beryx splendens could potentially reside remain poorly explored.

The occurrence of one crustacean, one fish, and some cephalopods in the stomach is consistent with the preferential diet of the species as reported for populations occurring in the Atlantic Ocean (Dürr and Gonzáles 2002). Prey items similar to those eaten by the fish in the Atlantic Ocean, are available in the deep habitats of the Mediterranean Sea. These might, therefore, represent suitable habitats for the establishment of the species.

Additionally, the observed advanced stage of gonadal maturation (close to spawning), was consistent with the observations on other specimens caught in the Mediterranean (Ligas et al. 2010, Follesa et al. 2011, Psomadakis et al. 2012b). According to González et al. (2003), the spawning period of this species varies among different zones in the eastern Atlantic Ocean and normally extends for some months. In the light of observations made on individuals captured in the western Mediterranean Sea, the spawning season in this area is likely to start in mid-Summer.

In conclusion, the new record reported herein represents the 10th finding of the species in the Mediterranean basin (most of them occurred starting from 2001). According to the "CIESM Atlas of exotic species in the Mediterranean" criteria (that consider "established" those species that have self-maintaining populations as evidenced by a minimum of three published records from either different localities or in different periods) (Golani et al. 2013), we can consider the splendid alfonsino as "established" in the western Mediterranean.

\section{ACKNOWLEDGEMENTS}

The authors thank Corrado D'Ercole for the precious gift of the specimen and for the information given, which were necessary to contextualize the catch. Such collaborative relationship highlights the importance of the fisheries for the development of marine biological knowledge. 


\section{REFERENCES}

Akimoto S., Itoi S., Sezaki K., Borsa P., Watabe S. 2006. Identification of alfonsino, Beryx mollis and $B$. splendens collected in Japan, based on the mitochondrial cytochrome $b$ gene, and their comparison with those collected in New Caledonia. Fisheries Science 72 (1): 202-207. DOI: 10.1111/j.1444-2906.2006.01136.x

Ariola V. 1904. Pesci nuovi o rari per il Golfo di Genova. [New or rare fish for the Gulf of Genoa]. Annali del Museo Civico di Storia Naturale di Genova. 1: 154168. [In Italian.]

Bellotti C. 1891. Appunti all'Opera di E. Moreau. [Notes to the Opera of E. Moreau]. Atti della Società Italiana di Scienze Naturali, Genova 33: 107-143. [In Italian.]

Busakhin S.V. 1982. Systematics and distribution of the family Berycidae (Osteichthyes) in the World Ocean. Journal of Ichthyology 22 (6): 1-21.

Danovaro R., Company J.B., Corinaldesi C., D'Onghia G., Galil, B., Gambi C., Gooday A.J., Lampadariou N., Luna G.M., Morigi C., Olu K., Polymenakou P., Ramirez-Llodra E., Sabbatini A., Sardà F., Sibuet M., Tselepides A. 2010. Deep-sea biodiversity in the Mediterranean Sea: The known, the unknown, and the unknowable. PLoS One. 5 (8): e11832. DOI: 10.1371/ journal.pone.0011832

Dürr J., Gonzáles J.A. 2002. Feeding habits of Beryx splendens and Beryx decadactylus (Berycidae) off the Canary Islands. Fisheries Research 54 (3): 363-374. DOI: 10.1016/S0165-7836(01)00269-7

Follesa M.C., Mulas A., Porcu C., Cau A. 2011. On the record of alfonsino Beryx splendens (Berycidae) in Sardinian seas (central-western Mediterranean). Cybium 35 (1): 77-78.

Gavagnin P., Garibaldi F., Orsi Relini L., Palandri G. 1992. Cattura di un raro pesce bericiforme nelle acque profonde del Mar Ligure. [Catch of a rare bericiform fish in the deep waters of the Ligurian Sea]. Oebalia 17 (2): 57-60. [In Italian.]

Golani D., Massuti E., Orsi Relini L., Quignard J.P., Dulčić J., Azzurro E. 2013. CIESM atlas of exotic fishes in the Mediterranean. [Accessed in December 2017] http://www.ciesm.org/atlas/appendixl.html

Golani D., Orsi Relini L., Massuti E., Quignard J.-P. 2002. CIESM atlas of exotic species in the Mediterranean. Vol. 1. Fishes. CIESM Publishers, Monaco.

González J.A., Rico V., Lorenzo J.M., Reis S., Pajuelo J.G., Afonso Dias M., Mandonça A., Krug H.M., Pinho M.R. 2003. Sex and reproduction of the alfonsino Beryx splendens (Pisces, Berycidae) from the Macaronesian archipelagos. Journal of Applied Ichthyology 19 (2): 104-108. DOI: 10.1046/j.14390426.2003.00358.x

Holden M.J., Raitt D.F.S. 1974. Manual of fisheries science. Part 2. Methods of resource investigation and their application. FAO Fisheries Technical Paper No. 115.

Horn P.L., Massey B.R. 1989. Biology and abundance of alfonsino and bluenose off the lower east coast
North Island, New Zealand. New Zealand Fisheries Technical Report No. 15.

Iglésias S.P., Frotté L. 2015. Alien marine fishes in Cyprus: Update and new records. Aquatic Invasions 10 (4): 425-438. DOI: 10.3391/ai.2015.10.4.06

Lebedev N.V. 1946. Èlementarnye populâcii ryb. [Elementary populations of fish.] Zoologičeskij Žurnal 25 (2): 121-135. [In Russian.]

Lehodey P., Grandperrin R., Marchal P. 1997. Reproductive biology and ecology of a deep-demersal fish, alfonsino Beryx splendens, over the seamounts off New Caledonia. Marine Biology 128 (1): 17-27. DOI: $10.1007 / \mathrm{s} 002270050064$

Ligas A., Sirna R., Ferroni O. 2010. New record of Beryx splendens Lowe, 1834 in the Mediterranean Sea. Journal of Applied Ichthyology 26 (6): 935-936. DOI: $10.1111 /$ j.1439-0426.2010.01514.x

Magnuson J.J. 1969. Digestion and food consumption by skipjack tuna (Katsuwonus pelamis). Transactions of American Fisheries Society 98 (3): 379-392. DOI: 10.1577/1548-8659(1969)98[379:DAFCBS]2.0.CO;2

Maul G.E. 1986. Berycidae. Pp. 740-742. In: Whitehead P.J.P., Bauchot M.-L., Hureau J.-C. Nielsen, J., Tortonese E. (eds.) Fishes of the North-eastern Atlantic and the Mediterranean, Vol. 2. UNECSO, Paris.

Moore J.A. 2002. Berycidae. Pp. 1189-1191.In: Carpenter K.E. (ed.) The living marine resources of the western central Atlantic. Bony fishes, Part 1 (Acipenseridae to Grammatidae). FAO species identification guide for fisheries purposes, Vol. 2. FAO, Rome.

Orsi Relini L. 2010. Non native marine fish in Italian waters. Pp. 267-292. In: Golani D., AppelbaumGolani B. (eds.) Fish invasions of the Mediterranean Sea: Changes and renewal. Pensoft Publishers, Series Faunistica No. 91, Sofia, Bulgaria.

Orsi Relini L., Palandri G., Garibaldi F. 1995. First record of Beryx splendens (Osteichthyes, Berycidae) in the Mediterranean. Cybium 19 (3): 317-319.

Psomadakis P.N., Scacco U., Vacchi M. 2006. Recent findings of some uncommon fishes from the central Tyrrhenian Sea. Cybium 30 (4): 297-304.

Psomadakis P.N., Giustino S., Vacchi M. 2012a. Mediterranean fish biodiversity: An updated inventory with focus on the Ligurian and Tyrrhenian seas. Zootaxa 3263: 1-46.

Psomadakis P.N., Stefanni S., Merella P., Ferrando S., Amato A., Vacchi M. 2012b. Additional records of Beryx splendens (Osteichthyes: Berycidae) from the Mediterranean Sea, with notes on molecular phylogeny and parasites. Italian Journal of Zoology 79 (1): 111-119. DOI: 10.1080/11250003.2011.602647

Rico V., Lorenzo J.M., González J.A., Krug H.M., Mendonça A., Gouveia E., Dias M.A. 2001. Age and growth of the alfonsino Beryx splendens Lowe, 1834 from the Macaronesian archipelagos. Fisheries Research 49 (3): 233-240. DOI: 10.1016/S01657836(00)00206-X

Yoshino T., Kon T., Miura A. 1999. Morphological differences between Beryx splendens and B. mollis Abe 
(Teleostei: Beryciformes: Berycidae). Bulletin of the Faculty of Science, University of the Ryukyus 67: 77-86.

Yoshino T., Kotlyar A.N. 2001. World distribution of the baloon alfonsin, Beryx mollis (Pisces: Beryciformes: Berycidae). Bulletin of the Faculty of Science, University of the Ryukyus 72: 119-123.

Zenetos A., Gofas S., Morri C., Rosso A., Violanti D., García Raso J.E., Çinar M.E., Almogi-Labin A., Ates A.S., Azzurro E., Ballesteros E., Bianchi C.N., Bilecenoglu M., Gambi M.C., Giangrande
A., Gravili C., Hyams-Kaphzan O., Karachle P.K., Katsanevakis S., Lipej L., Mastrototaro F., Mineur F., Pancucci-Papadopoulou M.A., Ramos-Esplá A., Salas C., San Martín G., Sfriso A., Streftaris N., Verlaque M. 2012. Alien species in the Mediterranean Sea by 2012. A contribution to the application of European Union's Marine Strategy Framework Directive (MSFD). Part 2. Introduction trends and pathways. Mediterranean Marine Science 13 (2): 328 352. DOI: $10.12681 / \mathrm{mms} .327$

Received: 8 November 2017

Accepted: 19 February 2018

Published electronically: 30 June 2018 